\title{
Modeling Metastatic Breast Cancer in Mice
}

\author{
Jos Jonkers • Patrick W. B. Derksen
}

Published online: 21 June 2007

(C) Springer Science + Business Media, LLC 2007

\begin{abstract}
Metastatic disease is the major cause of death in breast cancer patients. Patients presenting with metastases cannot be cured, and as a consequence, treatment is palliative and focuses on prolonging survival and maintaining quality of life. Numerous mouse models have been generated in which human breast cancer development and metastasis have been studied, ranging from spontaneous and carcinogen-induced models to transplantation models and genetically engineered mouse models. Here, we summarize past progress and highlight present developments in modeling breast cancer invasion and metastasis in genetically modified mice, and the impact it may have on the development of innovative anticancer therapies.
\end{abstract}

Keywords Mouse model · Breast cancer · Metastasis ·

Mammary gland · Transgenic

\section{Introduction}

Breast cancer is the most common malignancy among females in the Western world, resulting in approximately half a million deaths annually mainly due to metastatic disease [1]. While primary breast tumors can be treated with increasing success, many tumors are not eradicated by

J. Jonkers $(\triangle) \cdot$ P. W. B. Derksen

Division of Molecular Biology, Netherlands Cancer Institute,

Plesmanlaan 121,

1066CX Amsterdam, The Netherlands

e-mail: j.jonkers@nki.nl

Current Address:

P. W. B. Derksen

Department of Medical Oncology,

University Medical Center Utrecht,

Universiteitsweg 100 ,

3584 CG Utrecht, The Netherlands

e-mail: p.derksen@nki.nl local treatment and systemic adjuvant therapy, and will relapse, often leading to the incurable phase of cancer, metastatic disease. Although frequently regarded as such, tumors are not a homogeneous population of immortalized cells. Recent data have shown that a primary tumor consists of several populations of malignant cells, each of which may respond differently to conventional treatment [2, 3]. Specifically, certain tumor cells that present 'stem cell like' characteristics were shown to be causal to radiotherapy resistance [4-6]. In analogy to this, approximately $40 \%$ of breast cancer patients show resistance to standard chemotherapy, resulting in tumors that will relapse and subsequently metastasize.

Metastatic disease is a complex phenomenon, in which cells have to detach from their microenvironment, counteract the resulting pro-apoptotic signals, invade surrounding stroma, enter the vasculature and colonize distant sites. These processes depend on the activation and inhibition of multiple signal transduction pathways and their targets, which are currently ill defined. Research on breast cancer metastasis has greatly profited from recent advances in modeling metastatic disease in mice, using both transplantation techniques and genetic modification $[7,8]$. Due to the complex nature of the metastatic process, models that mimic the entire disease are scarce, but nevertheless emerging. This review will focus on past and present mouse models in which breast cancer invasion and metastasis are studied. We will discuss the lessons learned from these models and the usefulness of the resulting data in the identification of targets for drug development.

\section{Human Breast Cancer}

Breast cancer is a genetic disease and, consequently, its incidence increases with age. Among the numerous risk factors (e.g. late menopause, nulliparity, long term post menopausal hormonal replacement therapy, obesity and 
alcohol) the most predictive risk factor is a family history of breast cancer [9]. Approximately $5-10 \%$ of all breast cancers result from certain forms of hereditary cancer predisposition, such as Li-Fraumeni syndrome [10, 11], Cowden's disease [12], and BRCA mutation carriers [13]. All breast cancers, however, have acquired somatic genetic abnormalities, resulting in mutated or overexpressed cancer genes (e.g. TP53, MYC, BCL2, CCND1) [14]. Large-scale sequencing of breast cancer genomes is currently being performed by several groups $[15,16]$, but the exact number and type of mutations that are required for breast cancer initiation and metastasis in humans is still unknown.

\section{Breast Cancer Progression and Metastasis}

Breast cancer is a clinically heterogeneous disease. Aggressive breast cancers not only show multiple morphological phenotypes, the rate and onset at which metastasis occurs also varies considerably. For example, aggressive disease with distant metastases within 3 years, as well as manifestation of distant metastases more than 10 years after initial diagnosis are not uncommon [17]. Sites of metastasis may differ per subtype, but mainly comprise lung, pleura, liver and bone [18] (Fig. 1). Human pathology has defined a plethora of histological subtypes, based mainly on morphological criteria, of which ductal and lobular carcinomas represent the majority (Table 1). Although informative, the ductal and lobular classification is a poor prognostic indicator of metastatic risk [19] and can be misleading, as it implies cellular origin. To better define the basis of breast cancer heterogeneity, gene expression profiling has recently been used to identify molecular subtypes of breast cancer with distinct clinical features [20, 21]. Similarly, supervised classification of gene expression profiling data has yielded prognostic gene expression signatures that predict risk of breast cancer metastasis [22, 23]. Yet other groups have identified gene expression signatures that predict the site of metastasis $[24,25]$. Tumor or metastasis-specific expression profiles can thus help to point to distinct signaling pathways that contribute to metastasis. In this way, "tailored" intervention strategies may be developed to improve the currently relatively poor clinical management in both the adjuvant and metastatic setting [9-14]. Conventional prognostic markers that predict or correlate with breast cancer metastasis are not very reliable and are mainly based on phenotypic criteria, such as tumor size, histological grade, lymph node status and (lymph)angioinvasion [26-29]. More recently, clinicians have also employed the aberrant expression of proteins ( $\mathrm{UPA} / \mathrm{PAI} 1$, steroid receptors, ERBB2) to predict disease outcome [28-32], or as targets for intervention strategies [33, 34].

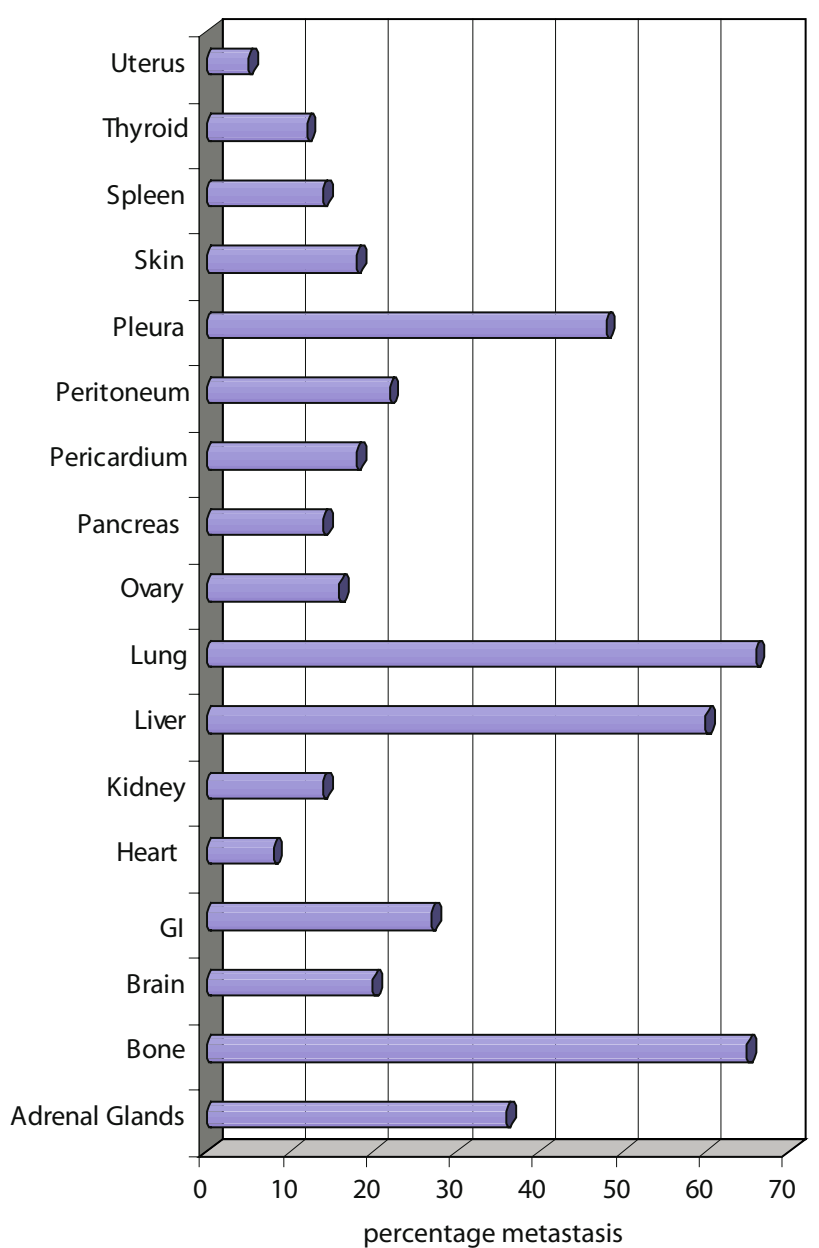

Figure 1 Dissemination sites of breast cancer metastasis at autopsy. Percentages obtained from 2,050 cases are shown. Adapted from [18].

\section{Breast Cancer Diagnosis and Treatment}

Systemic screening by means of mammography may result in early diagnosis, depending on tumor subtype. These clinical examinations have resulted in a $25-30 \%$ decrease in mortality from breast cancer, mainly in postmenopausal women [35]. Among women with breast cancer who present tumors less then $2 \mathrm{~cm}$ in diameter, or up to $5 \mathrm{~cm}$ without signs of axillary node metastasis, the 20 year recurrence-free survival is approximately 77 and 64\%, respectively $[27,36]$. Given the fact that predictions regarding recurrence and metastasis are difficult to make, systemic adjuvant therapy following local treatment is now widely applied to help eradicate tumor cells that might have already spread systemically $[9,37]$. Currently, depending on the guidelines used, 50 to over $80 \%$ of breast cancer patients receive adjuvant therapy, even though only 25 $40 \%$ of them will relapse and ultimately die of metastatic disease [38]. Hence, many women are 'over-treated' and will suffer unnecessarily from the harmful side effects of standard chemotherapy. Adjuvant chemotherapy regimens 
Table 1 Histopathological subtypes of invasive breast carcinoma.

\begin{tabular}{lll}
\hline Breast cancer subtype & Frequency (\%) & $10-$ year survival (\%) \\
\hline $\begin{array}{l}\text { Invasive ductal carcinoma } \\
\text { (IDC) }\end{array}$ & $50-80$ & $35-50$ \\
$\begin{array}{l}\text { Invasive lobular carcinoma } \\
\text { (ILC) }\end{array}$ & $5-15$ & $35-50$ \\
Mixed & $4-5$ & $35-50$ \\
Tubular/invasive & $1-6$ & $90-100$ \\
$\quad$ cribriform & & \\
Mucinous & $<5$ & $80-100$ \\
Medullary & $1-7$ & $50-90$ \\
Invasive papillary & $<3$ & Unknown \\
Metaplastic & $<5$ & Unknown \\
\hline
\end{tabular}

Adapted from [38].

often consist of repetitive administrations of combinations of drugs [39]. Frequently used combinations are CMF (cyclophosphamide, methotrexate, fluorouracil), FAC (fluorouracil, doxorubicin, cyclophosphamide), FEC (fluorouracil, epirubicin, cyclophosphamide) and AC (doxorubicin, cyclophosphamide), sometimes followed by a taxane [9]. These therapies are followed by endocrine therapy in case of hormone receptor-positive disease, and combined with the anticancer drug trastuzumab in case of ERBB2 gene amplification [40]. Other targeted therapies against VEGF and EGFR are now in advanced stages of clinical testing. In addition to these therapies, scores of other small molecule inhibitors and biologicals that antagonize the activity of specific enzymes or protein-protein interactions are currently under development [33].

\section{Mouse Models of Human Breast Cancer}

Mouse models have made an important contribution to our understanding of breast cancer progression and metastasis. Novel, 'humanized' mouse models are at present being developed and will be pivotal to pinpoint the cardinal events that govern intrinsic cues of tumor cells and microenvironmental interactions that propel metastatic disease. Also, they will be important tools to test and validate novel treatment strategies.

\section{Mice are Not Little Humans}

The laboratory mouse has been used extensively in cancer research for a number of reasons. First, the mouse is a mammalian organism that shares many anatomic, physiological and genetic similarities with humans. Second, the mouse germ line can be easily manipulated whereby genes may be overexpressed or inactivated, even in a time or tissuespecific manner. These characteristics render mice very attractive as a study object for human cancer pathogenesis.
But how alike are mice and men? Does a mouse mammary tumor truthfully reflect human breast cancer?

Mice are about 3,000 times smaller, live on average 40 times shorter and undergo approximately 100,000 fewer cell divisions in their lifetime than humans. Yet, they are as susceptible to developing cancer as humans [41]. Despite the fact that mice should experience far less genetic damage during their relatively short life span, both mice and men show a cumulative cancer incidence of approximately $30 \%$. Thus, humans must have evolved intrinsic anti-tumor mechanisms which have allowed them to decrease cancer susceptibility [42]. Mice mainly tend to develop tumors of mesenchymal origin, whereas human age-related cancers are mostly derived from epithelial progenitor cells [43]. Apart from the obvious environmental factors, such as alcohol, diet and tobacco, there are clear biological differences between mice an men that are likely to contribute to differences in cancer risk and spectrum. One major difference comprises telomere erosion during malignant transformation of human cells. In contrast to human cells, mouse somatic cells express biologically active telomerase, an enzyme that is required for maintenance of chromosome ends [44]. Accordingly, mouse telomeres are 40 to 60 times longer than human telomeres and, consequently, mouse cells are more easily immortalized than human cells, which must undergo a second genetic hit to overcome telomere crisis [45]. Despite these discrepancies, mouse models have demonstrated their utility in cancer research and have made a substantial contribution in understanding human tumor etiology.

\section{The Mouse Mammary Gland}

In order for the stem cells in the neonatal mammary bud to develop into an adult mammary gland, progenitor cells need to propel and maintain a delicate and fine-tuned balance of multiple signaling pathways. These pathways, which include among others Wnt, Notch, EGF, and TGF signaling, are triggered to enable cells to invade stroma, proliferate, acquire anoikis resistance, undergo apoptosis, differentiate and induce angiogenesis [46, 47]. Also, stromal elements present in the mammary gland, such as adipocytes, fibroblasts, endothelial and immune cells, will intricately interact with mammary epithelium in order to successfully form a functional mammary gland [48]. These processes not just are used for mammary gland development; during pregnancy, the mammary gland undergoes similar morphological and environmental changes. An enormous response is displayed upon release of female reproductive hormones, including the induction of mammary gland formation, differentiation of cells into milksecreting units and subsequent massive involution after parturition. It is this remarkable flexibility of mammary 
epithelial cells that breast cancer cells hijack during their progression and metastasis.

\section{Transplantation Models of Breast Cancer}

Transplantation of cells derived from breast cancer has been extensively used to study several aspects of breast cancer pathology in situ. A major factor to be considered, however, is the site of tumor cell injection. For example, several aspects of the metastatic process (tumor-stroma interactions, detachment and local invasion, extravasation) are omitted when injecting tumor cells into a vein (IV). Injections into the left ventricle of the heart (intracardiac; IC) which excludes the direct trapping of tumor cells in the lungs, facilitate a broader dissemination spectrum and are thus successfully being using to study bone metastasis [49]. Orthotopic transplantations, and to a lesser extent ectopic transplantations, mimic additional aspects of metastasis, because cells have to form a primary tumor as well as actively trigger local invasion and extravasation, which are key aspects of metastasis.

\section{Allograft Models}

Transplantation of tumor cells into syngeneic recipient mice with identical genetic backgrounds (allografting) prevents graft versus host reactions, which is a problem when studying human cancer cells in mice (xenografting). Most allograft models do not show extensive metastatic behavior, especially to bone. Nevertheless, specific selection in vivo has resulted in cancer cell lines (e.g. 4T1.2 cells derived from a spontaneous BALB/C mammary tumor) that show enhanced metastatic potential to lungs, liver, bone and brain when injected intracardiacally or at orthotopic sites [50, 51]. Gene expression profiling of several 4T1.2 sublines with different metastatic potential has led to the identification of Twist as a key factor in breast cancer metastasis [52]. Twist may contribute to metastasis by promoting an epithelial to mesenchymal transition (EMT) characterized by loss of E-cadherin-mediated cell-cell adhesion, activation of mesenchymal markers, and induction of cell motility.

\section{Xenograft Models}

Metastasis can be also studied by transplantation of human tumor cells in mice, a technique that is restricted to immune-compromised or immune deficient animals because of the inevitable host versus graft reactions [53, 54]. As a consequence, the contribution of an intact immune system - which plays a key role in the metastatic processcannot be studied in these xenograft models. Also, stromal components that can foster carcinoma-associated fibroblasts have been shown to activate and maintain SDF1-mediated signaling and subsequent induction of angiogenesis $[55,56]$. Despite these limitations, several studies have successfully utilized a human cell line, MDA-MB-231, in the search for factors that regulate metastasis. This cell line is derived from pleural effusion fluids of a breast cancer patient, and displays colonization of multiple target organs, such as liver, lung, brain, adrenal glands and bone upon orthotopic and subcutaneous transplantation [57, 58]. Massagué and colleagues have successfully used in vivo selection of MDA-MB-231 cells in nude mice to identify and validate genes that control metastasis to bone and lung [24, 25]. Bone metastatic subpopulations of MDA-MB-231 cells were selected by several rounds of intracardiac injections and isolation of metastatic nodules in the bones of the injected mice [25]. Lung metastatic variant sublines of MDA-MB-231 were selected by repeated tail vein injections and isolation of lung lesions [24]. Subsequent gene expression profiling of parental MDA-MB-231 cells and metastatic variants yielded sets of genes that promote metastasis to bone or lung. Bone metastasis of MDA-MB231 cells appears to be mediated by a limited number of genes, including the angiogenesis factors $F G F 5$ and $C T G F$, the activator of osteoclast differentiation IL11, the bone matrix-degrading metalloproteinase $M M P 1$ and the bonehoming chemokine receptor $C X C R 4$ [25]. CXCR4, which is highly expressed in human breast cancer cells, is an important determinant for organ-specific metastasis because CXCR4-positive tumor cells are actively recruited by SDF1-expressing metastatic target organs [59]. Gene expression profiling of lung metastatic MDA-MB-231 variants yielded a set of 54 genes including-besides CXCL1, MMP1 and MMP2-the EGF family member $E R E G$, the cell adhesion molecule $S P A R C$, the cell adhesion receptor VCAM1, the interleukin receptor IL13RA2, the inhibitor of cell differentiation $I D 1$ and the cyclooxygenase COX2 [24]. Functional validation of these genes showed that some (e.g. IDI) serve dual functions in both the primary tumor and in the lung microenvironment, whereas others (e.g. IL13RA2, SPARC and VCAM1) contribute only to lung metastasis formation.

\section{Xenografting in Humanized Mice}

Obviously, caution should be taken when transplanting human tumor cells into mice, as human cells are not fully adapted to the mouse microenvironment. Indeed, attempts to recapitulate human breast epithelial morphogenesis by introducing human MECs into cleared mammary fat pads of mice have been unsuccessful. To circumvent this limitation, Kuperwasser and coworkers have developed an orthotopic xenograft model in which both the stromal and epithelial components of the reconstituted mammary gland 
are of human origin [60]. To this end, mouse mammary fat pads were "humanized" by introducing human breast fibroblasts into cleared mouse glands, and at a later time point engrafting human breast epithelial and stromal cells into the humanized fat pads. This system allows for full developmental and functional outgrowth of human breast ducts and lobules and permits orthotopic grafting of primary human breast cancer tissue and cells. Another strategy to produce humanized mouse xenograft models of breast cancer metastasis involves injection of human breast cancer cells into immunodeficient NOD/SCID mice carrying human bone grafts [61]. Of 13 breast cancer cell lines tested, only SUM1315 cells formed lung and bone metastases. Importantly, bone metastasis was to the human implant and not to the mouse skeleton, suggesting species-specific homing characteristics.

\section{Conventional Transgenic Mouse Models of Breast Cancer}

Historically, mammary gland-specific overexpression of oncogenes has been the primary means to study breast cancer in transgenic mice. The initial oncogenes to be discovered were genes found overexpressed through genomic amplification in human breast cancers, or genes identified as targets of mouse mammary tumor virus (MMTV) insertional mutagenesis experiments [62, 63]. Consequently, the
MMTV long terminal repeat (MMTV-LTR), which contains the retroviral promoter and enhancer elements, has been widely employed to drive mammary gland-specific overexpression of a gene of interest in transgenic mice [64]. Also, other promoters, mainly derived from genes encoding mammary gland-specific (lactogenic) proteins, have been used to create a multiplicity of transgenic mouse models of breast cancer. An overview of promoters used for mammary gland-specific transgenesis is shown in Table 2. A negative aspect of many of these models is that tumors have to be induced by hormonal stimuli, triggering not only transgene expression but also developmental cues, which may affect tumor etiology. Conversely, female reproductive stimuli are also present systemically in the absence of pregnancy or lactation and can therefore induce undesired expression of transgenes, a known phenomenon when using, for example, whey acidic protein (WAP) promoter elements. Also, lymphatic dissemination and subsequent metastasis, especially to bone, are rare in conventional transgenic mouse models, which is most likely due to the rapid onset and progression of the primary neoplasm [8] (Table 3). In an ideal world, the promoters used in mouse models should not only be mammary-specific, but also hormone-independent. This requirement induces an intrinsic paradox that has prevented the development of the ultimate model using the aforementioned tools.

Table 2 Promoters used for mammary gland-specific expression.

\begin{tabular}{|c|c|c|c|c|c|c|}
\hline Promoter element & Abbreviation & Expression & Activation & Strengths & Weaknesses & Reference \\
\hline $\begin{array}{c}\text { Mouse mammary } \\
\text { tumor virus long } \\
\text { terminal repeat }\end{array}$ & MMTV & $\begin{array}{l}\text { Mammary } \\
\text { epithelium, several } \\
\text { other tissues }\end{array}$ & $\begin{array}{l}\text { Steroid } \\
\text { hormones }\end{array}$ & Strong promoter & $\begin{array}{l}\text { Requires } \\
\text { pregnancy } \\
\text { Expressed in } \\
\text { other tissues }\end{array}$ & [118] \\
\hline $\begin{array}{l}\text { Whey acidic } \\
\text { protein }\end{array}$ & WAP & $\begin{array}{l}\text { Mammary } \\
\text { epithelium }\end{array}$ & $\begin{array}{r}\text { Lactogenic } \\
\text { hormones }\end{array}$ & $\begin{array}{l}\text { Mammary gland- } \\
\text { specific }\end{array}$ & $\begin{array}{l}\text { Requires } \\
\text { pregnancy }\end{array}$ & {$[119,120]$} \\
\hline $\begin{array}{l}\text { Bovine } \beta \text { - } \\
\text { lactoglobulin }\end{array}$ & BLG & $\begin{array}{l}\text { Mammary } \\
\text { epithelium, salivary } \\
\text { gland }\end{array}$ & $\begin{array}{l}\text { During } \\
\text { mammary } \\
\text { development and } \\
\text { lactation }\end{array}$ & $\begin{array}{l}\text { Mammary gland- } \\
\text { specific }\end{array}$ & $\begin{array}{l}\text { Requires } \\
\text { pregnancy }\end{array}$ & {$[121]$} \\
\hline $\begin{array}{l}\text { Rat prostate } \\
\text { steroid-binding } \\
\text { protein }\end{array}$ & $\mathrm{C} 3(1)$ & $\begin{array}{c}\text { Prostate and } \\
\text { mammary } \\
\text { epithelium }\end{array}$ & Estrogen & $\begin{array}{l}\text { Does not require } \\
\text { pregnancy }\end{array}$ & $\begin{array}{l}\text { Expressed in } \\
\text { other tissues }\end{array}$ & {$[122]$} \\
\hline Metallothoinin & MT & $\begin{array}{l}\text { Many tissues, } \\
\text { including } \\
\text { mammary gland }\end{array}$ & Zinc ions & $\begin{array}{l}\text { Does not require } \\
\text { pregnancy Expression } \\
\text { inducible with } \mathrm{Zn}^{2+}\end{array}$ & $\begin{array}{l}\text { Expressed in } \\
\text { many other } \\
\text { tissues }\end{array}$ & {$[123]$} \\
\hline Cytokeratin 14 & K14 & $\begin{array}{l}\text { Skin, mammary } \\
\text { epithelium salivary } \\
\text { gland, thymus }\end{array}$ & & $\begin{array}{l}\text { Does not require } \\
\text { pregnancy }\end{array}$ & $\begin{array}{l}\text { Expressed in } \\
\text { other tissues }\end{array}$ & {$[124]$} \\
\hline H19 & H19 & $\begin{array}{l}\text { (Embryonic) } \\
\text { mammary gland, } \\
\text { lung, liver }\end{array}$ & $\begin{array}{l}\text { Genetic } \\
\text { imprinting, de- } \\
\text { methylation }\end{array}$ & & $\begin{array}{l}\text { Expressed in } \\
\text { other tissues }\end{array}$ & {$[125]$} \\
\hline
\end{tabular}




\section{Conventional Transgenics: Polyoma Virus Middle T Antigen}

The Polyoma middle T-antigen (PyMT) has the ability to convert established cell lines to an oncogenic state. Middle $\mathrm{T}$ antigen is a membrane bound polypeptide that can be regarded as a constitutively active analogue of a receptor that harbors docking sites for a number of effector proteins used by tyrosine kinase receptors to stimulate mitogenesis
[65]. Mammary gland-specific overexpression of PyMT using the MMTV promoter results in multifocal adenocarcinomas with a short median latency and the formation of metastasis to lungs and lymph nodes [66]. This mouse model has since been used extensively because it shares many characteristics with human breast tumors. First, tumors develop with high penetrance and show gradual loss of estrogen and progesterone receptors. Second, the multistage progression from hyperplasia to a full-blown

Table 3 Mouse models of breast cancer metastasis.

\begin{tabular}{|c|c|c|c|c|c|c|}
\hline \multirow{2}{*}{$\begin{array}{l}\text { Promoter } \\
\text { element }\end{array}$} & \multicolumn{3}{|l|}{ Transgene } & \multirow{2}{*}{$\begin{array}{l}\text { Tumor } \\
\text { Latency } \\
\text { (days) }\end{array}$} & \multirow[t]{2}{*}{ Site of metastasis } & \multirow[t]{2}{*}{ Reference } \\
\hline & 1 & 2 & 3 & & & \\
\hline $\mathrm{C} 3(1)$ & SV40 LT & & & 180 & Lung & {$[126]$} \\
\hline H19 & Igf2 & & & $>280$ & Lung, liver, spleen & {$[125]$} \\
\hline MT & $\operatorname{Met}\left(\mathrm{Y} 1248 \mathrm{H}\right.$ and M1268T) ${ }^{\mathrm{a}}$ & & & 300 & Lung, LN, kidney, heart & {$[88]$} \\
\hline MMTV & Cox-2 & & & 210 & $\mathrm{LN}$ & {$[127]$} \\
\hline MMTV & Wnt-1 & & & 240 & Lung, LN & {$[118]$} \\
\hline MMTV & Wnt1 & Fgf-3 & & 120 & Lung, LN & {$[128]$} \\
\hline MMTV & Ron & & & 200 & Lung, liver & [92] \\
\hline MMTV & $\Delta \mathrm{N} \beta$-catenin & $\operatorname{Trp} 53^{\Delta /+}$ & & 300 & Lung & {$[128]$} \\
\hline MMTV & $\mathrm{Chk} 2^{\mathrm{D} 347 \mathrm{~A}}$ & & & 290 & Lung, Spleen & [129] \\
\hline MMTV & ErbB2 & & & 200 & Lung & {$[77]$} \\
\hline MMTV & ErbB2 & TGF $\beta$ & & 200 & More lung metastases & {$[80]$} \\
\hline MMTV & ErbB2 & $\mathrm{TGF} \beta(\mathrm{SR} 2 \mathrm{~F})$ & & 240 & Less lung metastases & {$[82]$} \\
\hline MMTV & ErbB2 & $\mathrm{S} 1004 \mathrm{~A}$ & & 330 & More lung metastases & [130] \\
\hline MMTV & ErbB2 activated & & & 120 & Lung & {$[76]$} \\
\hline MMTV & ErbB2 (YB and YD) & & & $\sim 150$ & Lung & {$[78]$} \\
\hline \multirow[t]{3}{*}{ MMTV } & ErbB2 (YB) & TGF $\beta$ R1 (AAD) & & 270 & Lung & [131] \\
\hline & ErbB2 (YB) & TGF $\beta$ R2 $(\Delta$ cyt $)$ & & & Less extravascular & \\
\hline & ErbB2 (YD) & TGF $\beta R 1$ (AAD) & & & More extravascular & \\
\hline MMTV & ErbB2 (YD) & $\operatorname{ItgB} 4^{1355 \mathrm{~T}}$ & & 150 & Inhibition of metastasis & [132] \\
\hline MMTV & PyMT & & & $84-175$ & Lung, LN & {$[66]$} \\
\hline $\begin{array}{l}\text { MMTV and } \\
\text { MMTV-rtTA }\end{array}$ & РyMT & $\begin{array}{l}\text { TetO- } \\
\text { TGF } \beta 1^{\text {S223/225 }}\end{array}$ & & 55 & More lung metastases & [81] \\
\hline MMTV & PyMT & VEGF & & 40 & Lung & {$[72]$} \\
\hline MMTV & РyMT & $\operatorname{Irs} 1^{\Delta / \Delta}$ & & 80 & More lung metastases & {$[70]$} \\
\hline MMTV & PyMT & $\mathrm{uPA}^{\Delta / \Delta}$ & & 50 & More lung metastases & [69] \\
\hline MMTV & PyMT & $\mathrm{CD} 44^{\Delta / \Delta}$ & & 105 & More lung metastases & {$[68]$} \\
\hline MMTV & PyMT & $\mathrm{Plg}^{\Delta / \Delta}$ & & 50 & Less lung metastases & [71] \\
\hline MMTV & PyMT & $\operatorname{MEKK} 1^{\Delta / \Delta}$ & & 90 & Lung, delayed & [133] \\
\hline MMTV & PyMT & $\operatorname{TGF} \beta \mathrm{R} 2^{\mathrm{MG} \Delta}$ & & 60 & More lung metastases & [83] \\
\hline WAP & HGF & & & 50 & Lung & [89] \\
\hline WAP & RAS & & & 180 & Lung & [134] \\
\hline WAP & SV40 LT & & & 300 & Lung, LN & {$[135]$} \\
\hline WAP & Notch-4 & & & 200 & Lung & {$[136]$} \\
\hline MMTV-rtTA & ErbB2 activated & & & & Lung (reversible) & {$[107]$} \\
\hline $\begin{array}{l}\text { MMTV and } \\
\text { WAP-rtTA }^{b}\end{array}$ & Cre & $\operatorname{Trp} 53^{\mathrm{F} 5-6}$ & & $280 / 330$ & Lung, liver & {$[102]$} \\
\hline K14 & Cre & $\operatorname{Trp} 53^{\mathrm{F} 2-10}$ & $\mathrm{Cdh} 1^{\mathrm{F} 4-15}$ & 200 & $\begin{array}{l}\text { Lung, LN, liver, GI tract, } \\
\text { peritoneum, pancreas }\end{array}$ & {$[103]$} \\
\hline
\end{tabular}

${ }^{a}$ Only one animal was tested for each mutation.

${ }^{\mathrm{b}}$ Tet-responsiveness was not functional in this promoter. 
malignancy is represented in MMTV-PyMT mice. Finally, metastatic potential appears to be independent of hormonal fluctuations with a reproducible progression rate [67]. Several labs have employed the MMTV-PyMT model to define and substantiate a role for genes that have been implicated in tumor progression and metastasis, such as CD44 [68], uPA (69), Irs1[70] and Plg [71] (Table 3). Also, overexpression of the blood vessel angiogenic factor VEGF-A in MMTV-PyMT mice resulted in accelerated formation of lung metastasis, not only by promoting tumor angiogenesis but also by sustaining tumor proliferation and survival [72].

\section{Conventional Transgenics: Receptor Tyrosine Kinases}

The receptor tyrosine kinase (RTK) ErbB2 (aka Her2 or $\mathrm{Neu}$ ) has a long track record of clinical interest because of its overexpression in many breast tumors. Hence it is being used as a strong prognostic indicator, predictor of metastasis and a target for treatment [73]. ERBB2 is amplified in approximately 15 to $30 \%$ of all breast cancers [30], especially tumors from patients with lymph node metastases [74]. ErbB2 is an EGF family-type RTK, which normally regulates mammary growth and differentiation. Tissue culture experiments have shown that overexpression leads to transformation and invasion in the absence of ligand [75]. Transgenic mice that have been engineered to express wild type and mutant forms of ErbB2 under the control of MMTV promoter, show formation of multifocal adenocarcinomas that metastasize to lung [76-78].

Like the MMTV-PyMT model, the MMTV-ErbB2 mouse has formed the basis for many experiments to investigate cooperating events in breast cancer. A potent inducer of invasiveness is $\operatorname{TGF} \beta$, a secreted cytokine that exerts its activity by binding to distinct serine/threonine kinase receptors. Interaction of TGF $\beta$ with its receptor can have a dual outcome; it can suppress initial tumorigenesis, but conversely, can also stimulate invasion and metastasis, which is accompanied by an epithelial to mesenchymal transition (EMT) and proangiogenic and immune suppressive effects on the tumor microenvironment [79]. Furthermore, it has been shown to play a role as an important mediator of bone metastasis by increasing the expression of tissuespecific cytokines [25]. Expression of TGF $\beta$ in MMTVErbB2 mice caused more circulating tumor cells and lung metastases than ErbB2 mice alone. Furthermore, MMTVErbB2;MMTV-TGF $\beta 1$ tumors contained higher levels of active Smad2, Rac1, Pkb/Akt, MAPK and p38 [80]. Interestingly, primary tumor burden was unaltered regardless of TGF $\beta 1$ signaling. Inducible expression of TGF $\beta$ in the MMTV-PyMT mouse model of metastatic breast cancer also corroborated these findings [81]. In vivo inhibition by expressing either TGF $\beta$ antagonist SR2F, TGF $\beta$ receptor type I (TGF $\beta$ R1), or dominant negative TGF $\beta$ RII, reduced the number of lung metastases, thus substantiating the prometastatic functions of TGF $\beta 1$ signaling in MMTV-ErbB2 mice [82]. Somewhat intriguing is the finding that conditional ablation of TGF $\beta$ RII in the MMTV-PyMT mouse resulted in an increased number of metastatic lung foci [83].

Hyperactivation of hepatocyte growth factor (HGF) and its receptor MET can cause transformation of cells, leading to the initiation or progression of malignancy. Under these conditions, MET can disturb the subtle balance between growth and apoptosis, and induce unrestricted growth and motility, accounting for cellular transformation, invasion and metastasis [84]. Although activating mutations or genomic amplification have not been reported in human breast cancer, Met amplification is frequently observed in BRCA1- and p53-deficient mouse tumors [85]. Moreover, overexpression of MET has been found to predict metastasis and survival in early-stage breast cancer [86]. Zincinducible overexpression of HGF in MT-HGF mice resulted in diverse tumorigenesis, including mammary gland tumors, without apparent metastasis [87]. Overexpression of a mutant form of the Met receptor, but not the wild type protein, resulted in mammary tumors which metastasized to lung, lymph node (LN), kidney and heart [88], suggesting ligand-independent functions of mutant Met. Recently, HGF was overexpressed in the mammary gland using a WAP promoter, resulting in mammary tumors with a median latency of 210 days, which metastasize to the lungs [89]. The RON receptor is a family member of the Met proto-oncogene, and recently, RON has been found to be overexpressed and constitutively activated in approximately $50 \%$ of primary breast cancer cases [90]. In addition, increased expression of the RON receptor strongly correlates with the more aggressive phenotype observed in nodenegative breast tumors [91]. Transgenic overexpression of Ron in MMTV-Ron mice is sufficient to induce mammary tumors that metastasize to the liver and lungs with high penetrance. In contrast to the MET RTK, activating mutations in Ron did not confer a higher tumor incidence or metastasis rate [92].

\section{Conditional Mouse Models of Breast Cancer}

Human tumors are caused by accumulating genetic mutations in a distinct subset of cells that have a given susceptibility for the molecular consequences of such a mutation. In sporadic cancer, these mutations will affect a single cell that is embedded in a normal microenvironment. Conventional mouse models of human breast cancer have largely been based on the activation of a single dominant gene in a panorgan setting. As a consequence, a large cellular compartment is targeted for oncogenesis, a situation not reflective of the human condition. In human cancer, mutations occur sporad- 
ically in a stochastic manner and accumulate over time, leading to tumors with a distinct gene expression signature that determines metastatic behavior and clinical outcome [22]. Furthermore, most mouse mammary tumors arising in conventional transgenic models do not recapitulate the morphology of common human breast cancers [93]. Finally, tumor metastasis in conventional breast cancer models is largely restricted to lung, whereas most human tumors initially show lymphatic spread.

These limitations of conventional models have urged scientists to develop more advanced mouse models based on inducible systems that permit somatic and stochastic mutation of target genes in a wild type background [94]. Successful conditional gene (in)activation can be achieved by using site-specific recombination systems, such as the Cre/ loxP from bacteriophage $\mathrm{P} 1$ or the FLP/FRT system from $\mathrm{S}$. cerevisiae. To obtain a conditional mutation, coding regions of a gene are flanked by loxP or FRT elements, which are inserted in intronic sequences, resulting in functional alleles and phenotypically wild type animals. Mice carrying conditional mutations are then crossed to mice expressing the Cre or FLP recombinase enzyme in the mammary gland, and as a consequence, only those cells that have expressed the appropriate recombinase will undergo site-specific recombination resulting in deletion of the genomic sequences flanked by loxP or FRT elements [95] (See http:// www.mshri.on.ca/nagy/floxed.html posted by the Nagy lab for a database containing all published floxed genes). Future models may involve 'double-layered' systems in which tissue-specific, reversible gene mutations can be induced in selected (Cre-expressing) cells at any given time through the application of inducible (e.g. tetracycline-responsive) elements incorporated in mammary-specific promoters [96, 97]. Compound mutant mice can thus be bred to investigate the contribution of multiple mutant alleles, in space and time, to breast tumorigenesis and metastasis, providing an unsurpassed degree of flexibility in mouse modeling.

Another interesting system, which may facilitate in vivo testing of candidate metastasis genes, is based on avian leukosis virus RCAS (replication-competent avian sarcomaleukosis virus LTR splice acceptor)-mediated somatic gene transfer [98]. This system employs retroviral gene delivery whereby expression can be targeted to cells of mice transgenic for the avian subgroup A receptor gene (tva). This system has recently been employed successfully to introduce PyMT and ErbB2 in mammary epithelial cells of MMTV-tva transgenic mice [99]. Moreover, oncogene collaboration could be assessed by infection of MMTVtva; MMTV-Wnt bitransgenic mice with RCAS virus carrying an activated ErbB2 oncogene. The RCAS-tva system may thus be a promising approach to develop flexible mouse mammary tumor models for rapid evaluation of candidate metastasis genes.

\section{Conditional Mouse Models of Breast Cancer Metastasis}

Conventional mouse models of breast cancer employ activation or inhibition of genes in a "pan-organ" setting, and, as a consequence, produce mammary tumors that only poorly resemble human breast cancer etiology and metastatic behavior [93]. Hence, new mouse models are needed that reproduce the salient features of human breast cancer development and metastasis. Whereas these conditional mouse models of breast cancer metastasis are obviously more complex, the first successful studies show promising results.

Inhibition of $\mathrm{p} 53$ function as a consequence of mutation or genomic loss is found in approximately $50 \%$ of human breast cancer cases $[100,101]$. Conditional inactivation of p53 in the mammary gland using WAP promoter-driven Cre expression resulted in presumptive Er $\alpha$-positive tumors that metastasized to the lungs in $36 \%$ of the female mice [102]. However, major discrepancies exist between this model and human p53-mutated breast cancers, tumor morphology and metastatic spread. Possible reasons for these differences may be that (1) conditional mutations are induced in the wrong mammary gland compartment when using a WAP promoter, or (2) conditional induction of an additional hit is required to obtain a 'humanized' mouse mammary tumor with the appropriate metastatic spectrum.

The latter has been explored by studying the consequences of somatic loss of E-cadherin in a noninvasive mouse mammary tumor model based on epithelium-specific inactivation of p53. In this setting, stochastic cytokeratin (K)14 cre-mediated inactivation of E-cadherin induces the formation of mouse invasive lobular carcinoma (mILC), reminiscent of the human situation [103]. In contrast to previous mouse models, metastases in mILC are mostly lymphatic and spread to lung, liver, gastric tract and peritoneum, similar to human pathology. Moreover, angiogenesis is strongly increased in mILC, a phenotype that may be facilitated by autocrine production of proangiogenic factors. In summary, the mILC mouse model not only mimics a human form of breast cancer, but also represents the first physiologically relevant model to study all aspects of breast cancer progression and metastasis. The 'humanized' phenotype in mILC may be to a significant extent credited to a combination of the tissue-specific promoter used and the nature of the secondary induced conditional mutation. Given the tumor incidence and timing, carcinomas are likely to originate from a mammary gland progenitor cell that expresses CK14 before or during puberty. The main disadvantage of using a CK14 promoter to drive cre expression in mammary epithelium is the fact that this promoter is also active in other epithelial tissues, including skin. Consequently, a substantial fraction of the females develop skin tumors, which arise either prior to or concurrent with the onset of mILC. To circumvent these problems, we have developed a 
model, based on WAPcre-mediated deletion of E-cadherin and p53. Here, mammary tumors develop with a similar latency in a pregnancy-independent fashion and show a comparable metastatic spectrum and incidence (Derksen et al., manuscript in preparation).

\section{Regulatable Mouse Models of Breast Cancer Metastasis}

It is commonly accepted that tumor formation is a multistage process driven by stepwise acquisition of oncogenic capacities through (epi)genetic mutations in oncogenes and tumor suppressor genes [42]. An important question is whether an oncogene or tumor suppressor that is crucial for initial tumor development is also required for tumor maintenance. Tumors that are "addicted" to a specific genetic lesion might be effectively treated by genetic or pharmacological neutralization of this lesion, e.g. by inhibition of oncoprotein activity or restoration of tumor suppressor activity [104]. Using genetically engineered mouse models with doxycycline- or tamoxifen-inducible gene expression [95], this question has been successfully addressed for several oncogenes [105] and tumor suppressors, such as p53 [106]. These mouse models also permit assessment of the requirement of sustained oncogene overexpression for maintenance of tumor metastases. This issue has been elegantly tackled using a conditional mouse mammary tumor model with doxycycline-inducible, mammary epitheliumspecific expression of activated ErbB2 (MMTV-rtTA; TetO-ErbB2) [107]. Interestingly, addiction to activated ErbB2 is maintained during tumor progression and metastasis, since both primary mammary carcinomas and lung metastases rapidly and fully regress following transgene deinduction by doxycycline withdrawal. However, ErbB2independent tumors recurred in these animals over time.

\section{The Course Ahead}

Clearly, mouse models that recapitulate the multiple stages of breast cancer development and progression have greatly contributed to our understanding of the molecular mechanisms governing tumor progression and metastasis. Whereas comparative histopathology is often used to judge a mouse model on its merits, there is a growing appreciation for the underlying molecular mechanisms as the key parameters regulating tumorigenesis and progression. The fact that tumor progression in some mouse models does not 'look' like a human malignancy, does not exclude the possibility that the affected genes and pathways are similar or overlapping. Today, more and more emphasis is being directed towards molecular profiling techniques to identify deregulated pathways that drive tumor progression and metastasis. Humanized mouse models are increasingly being used to extract distinct genetic signatures that correspond to mam- mary tumors with specific metastatic capacity. This will allow a thorough comparison of mouse versus human expression profiles to extract common denominators for a given tumor phenotype or (organ-specific) metastatic pattern. These efforts are expected to yield candidates which may lead to the discovery of new diagnostic markers as well as drug targets for intervention strategies to fight metastatic disease. The final frontier will nonetheless be the testing of new strategies for clinical applicability. Although xenografts have extensively been used as preclinical models, they are end-stage tumors that do not recapitulate the natural history of cancer in a histocompatible host and, consequently, have not excelled in predictive power. Furthermore, they lack particular interactions with the microenvironment, which contains key elements that influence tumor development and metastasis [108-110]. Novel models of in vivo metastasis are being developed at an expeditious pace and will yield mice that closely resemble human tumor development and progression, thus allowing accurate testing of newly designed agents.

Moreover, tumor development and progression can be monitored noninvasively for long periods using a growing array of imaging modalities, such as bioluminescence imaging (BLI) [111], fluorescence imaging [112], magnetic resonance imaging (MRI) [113], positron emission tomography (PET) [114], computer tomography (CT) and single photon emission computed tomography (SPECT) [115]. Finally, intravital imaging using multiphoton or two-photon microscopy permits real time observation of the dynamics of tumor growth, extravasation and cell migration, as well as the contribution of stromal fibroblasts, endothelial cells and immune cells $[116,117]$. We believe the best is yet to come.

Acknowledgements We apologize to those whose work was not included because of space considerations. This work was supported by grants from the Dutch Cancer Society (NKI 2002-2635 and NKI 2006-3486 to JJ) and the Netherlands Organization for Scientific Research (NWO-Vidi 917.36.347 to JJ and NWO-Veni 916.56.135 to PWBD).

\section{References}

1. Althuis MD, Dozier JM, Anderson WF, Devesa SS, Brinton LA. Global trends in breast cancer incidence and mortality 19731997. Int J Epidemiol 2005;34:405-12.

2. Feinberg A, Ohlsson R, Henikoff S. The epigenetic progenitor origin of human cancer. Nat Rev Genet 2006;7:21-33.

3. Al Hajj M, Wicha MS, Benito-Hernandez A, Morrison SJ, Clarke MF. Prospective identification of tumorigenic breast cancer cells. Proc Natl Acad Sci USA 2003;100:3983-8.

4. Woodward WA, Chen MS, Behbod F, Alfaro MP, Buchholz TA, Rosen JM. WNT/beta-catenin mediates radiation resistance of mouse mammary progenitor cells. Proc Natl Acad Sci USA 2007;104:618-23. 
5. Bao S, Wu Q, McLendon RE, Hao Y, Shi Q, Hjelmeland AB, et al. Glioma stem cells promote radioresistance by preferential activation of the DNA damage response. Nature 2006;444:756-60.

6. Hambardzumyan D, Squatrito M, Holland EC. Radiation resistance and stem-like cells in brain tumors. Cancer Cell 2006;10:454-6.

7. Khanna C, Hunter K. Modeling metastasis in vivo. Carcinogenesis $2005 ; 26: 513-23$

8. Ottewell PD, Coleman RE, Holen I. From genetic abnormality to metastases: murine models of breast cancer and their use in the development of anticancer therapies. Breast Cancer Res Treat 2006;96:101-13.

9. Hortobagyi GN. Treatment of breast cancer. N Engl J Med 1998;339:974-84.

10. Malkin D, Li FP, Strong LC, Fraumeni JF, Jr., Nelson CE, Kim $\mathrm{DH}$, et al. Germ line p53 mutations in a familial syndrome of breast cancer, sarcomas, and other neoplasms. Science 1990;250:1233-8.

11. Srivastava S, Zou ZQ, Pirollo K, Blattner W, Chang EH. Germline transmission of a mutated p53 gene in a cancer-prone family with Li-Fraumeni syndrome. Nature 1990;348:747-9.

12. Eng C, Stratton M, Ponder B, Murday V, Easton D, Sacks N, et al. Familial cancer syndromes. Lancet 1994;343:709-13.

13. Marcus JN, Watson P, Page DL, Narod SA, Lenoir GM, Tonin P, et al. Hereditary breast cancer: pathobiology, prognosis, and BRCA1 and BRCA2 gene linkage. Cancer 1996;77:697-709.

14. Vogelstein B, Kinzler KW. Cancer genes and the pathways they control. Nat Med 2004;10:789-99.

15. Stephens P, Edkins S, Davies H, Greenman C, Cox C, Hunter C, et al. A screen of the complete protein kinase gene family identifies diverse patterns of somatic mutations in human breast cancer. Nat Genet 2005;37:590-2.

16. Sjoblom T, Jones S, Wood LD, Parsons DW, Lin J, Barber TD, et al. The consensus coding sequences of human breast and colorectal cancers. Science 2006;314:268-74.

17. Hellman S, Harris JR. Diseases of the Breast. Philadelphia: Lippincott Williams \& Wilkins; 2000. p 423.

18. Lee YT. Breast carcinoma: pattern of metastasis at autopsy. J Surg Oncol 1983;23:175-80.

19. Tavasolli FA, Devilee P. Organization classification of tumors. In: Pathology and genetics of tumors of the breast and female genital organs. Lyon: AICR; 2003. pp.

20. Sorlie T, Perou CM, Tibshirani R, Aas T, Geisler S, Johnsen H, et al. Gene expression patterns of breast carcinomas distinguish tumor subclasses with clinical implications. Proc Natl Acad Sci USA 2001;98:10869-74.

21. Perou CM, Sorlie T, Eisen MB, van de Rijn M, Jeffrey SS, Rees $\mathrm{CA}$, et al. Molecular portraits of human breast tumours. Nature 2000;406:747-52.

22. 't Veer LJ, Dai H, van de Vijver MJ, He YD, Hart AA, Mao M, et al. Gene expression profiling predicts clinical outcome of breast cancer. Nature 2002;415:530-6.

23. Wang Y, Klijn JG, Zhang Y, Sieuwerts AM, Look MP, Yang F, et al. Gene-expression profiles to predict distant metastasis of lymphnode-negative primary breast cancer. Lancet 2005;365:671-9.

24. Minn AJ, Gupta GP, Siegel PM, Bos PD, Shu W, Giri DD, et al. Genes that mediate breast cancer metastasis to lung. Nature 2005;436:518-24.

25. Kang Y, Siegel PM, Shu W, Drobnjak M, Kakonen SM, CordonCardo C, et al. A multigenic program mediating breast cancer metastasis to bone. Cancer Cell 2003;3:537-49.

26. Koscielny S, Tubiana M, Le MG, Valleron AJ, Mouriesse H, Contesso G, et al. Breast cancer: relationship between the size of the primary tumour and the probability of metastatic dissemination. Br J Cancer 1984;49:709-15.
27. Rosen PP, Groshen S, Saigo PE, Kinne DW, Hellman S. Pathological prognostic factors in stage I (T1N0M0) and stage II (T1N1M0) breast carcinoma: a study of 644 patients with median follow-up of 18 years. J Clin Oncol 1989;7:1239-51.

28. Page DL. Prognosis and breast cancer. Recognition of lethal and favorable prognostic types. Am J Surg Pathol 1991;15:334-49.

29. Pinder SE, Ellis IO, Galea M, O'Rouke S, Blamey RW, Elston CW. Pathological prognostic factors in breast cancer. III. Vascular invasion: relationship with recurrence and survival in a large study with long-term follow-up. Histopathology 1994;24:41-7.

30. Slamon DJ, Clark GM, Wong SG, Levin WJ, Ullrich A, McGuire WL. Human breast cancer: correlation of relapse and survival with amplification of the HER-2/neu oncogene. Science 1987;235:177-82.

31. Slamon DJ, Leyland-Jones B, Shak S, Fuchs H, Paton V, Bajamonde A, et al. Use of chemotherapy plus a monoclonal antibody against HER2 for metastatic breast cancer that overexpresses HER2. N Engl J Med 2001;344:783-92.

32. Harbeck N, Kates RE, Look MP, Meijer-van Gelder ME, Klijn JG, Kruger A, et al. Enhanced benefit from adjuvant chemotherapy in breast cancer patients classified high-risk according to urokinase-type plasminogen activator (uPA) and plasminogen activator inhibitor type $1(n=3,424)$. Cancer Research 2002;62: 4617-22.

33. Steeg PS. Tumor metastasis: mechanistic insights and clinical challenges. Nat Med 2006;12:895-904.

34. Cordera F, Jordan VC. Steroid receptors and their role in the biology and control of breast cancer growth. Seminars in Oncology 2006;33:631-41.

35. Berry DA, Cronin KA, Plevritis SK, Fryback DG, Clarke L, Zelen $\mathrm{M}$, et al. Effect of screening and adjuvant therapy on mortality from breast cancer. N. Engl. J Med 2005;353:1784-92.

36. Quiet CA, Ferguson DJ, Weichselbaum RR, Hellman S. Natural history of node-negative breast cancer: a study of 826 patients with long-term follow-up. J Clin Oncol 1995;13:1144-51.

37. Vervoort MM, Draisma G, Fracheboud J, van de Poll-Franse LV, de Koning. Trends in the usage of adjuvant systemic therapy for breast cancer in the Netherlands and its effect on mortality. Br J Cancer 2004;91:242-7.

38. Weigelt B, Peterse JL, 't Veer LJ. Breast cancer metastasis: markers and models. Nat Rev Cancer 2005;5:591-602.

39. Shapiro CL, Recht A. Side effects of adjuvant treatment of breast cancer. N Engl J Med 2001;344:1997-2008.

40. Geyer CE, Forster J, Lindquist D, Chan S, Romieu CG, Pienkowski T, et al. Lapatinib plus capecitabine for HER2positive advanced breast cancer. N Engl J Med 2006;355:273343.

41. Rangarajan A, Weinberg RA. Opinion: comparative biology of mouse versus human cells: modelling human cancer in mice. Nat Rev Cancer 2003;3:952-9.

42. Hanahan D, Weinberg RA. The hallmarks of cancer. Cell 2000;100:57-70.

43. DePinho RA. The age of cancer. Nature 2000;408:248-54.

44. Prowse KR, Greider CW. Developmental and tissue-specific regulation of mouse telomerase and telomere length. Proc Natl Acad Sci USA 1995;92:4818-22.

45. Rangarajan A, Hong SJ, Gifford A, Weinberg RA. Species- and cell type-specific requirements for cellular transformation. Cancer Cell 2004;6:171-83.

46. Hovey RC, Trott JF, Vonderhaar BK. Establishing a framework for the functional mammary gland: from endocrinology to morphology. J Mammary Gland Biol Neoplasia 2002;7:17-38.

47. Woodward WA, Chen MS, Behbod F, Rosen JM. On mammary stem cells. J Cell Sci 2005;118:3585-94. 
48. Wiseman BS, Werb Z. Stromal effects on mammary gland development and breast cancer. Science 2002;296:1046-9.

49. Rosol TJ, Tannehill-Gregg SH, LeRoy BE, Mandl S, Contag CH. Animal models of bone metastasis. Cancer 2003;97: $748-57$.

50. Aslakson CJ, Miller FR. Selective events in the metastatic process defined by analysis of the sequential dissemination of subpopulations of a mouse mammary tumor. Cancer Res 1992;52:1399-405.

51. Lelekakis M, Moseley JM, Martin TJ, Hards D, Williams E, Ho $\mathrm{P}$, et al. A novel orthotopic model of breast cancer metastasis to bone. Clin Exp Metastasis 1999;17:163-70.

52. Yang J, Mani SA, Donaher JL, Ramaswamy S, Itzykson RA, Come C, et al. Twist, a master regulator of morphogenesis, plays an essential role in tumor metastasis. Cell 2004;117:927-39.

53. Ozzello L, Sordat B, Merenda C, Carrel S, Hurlimann J, Mach JP. Transplantation of a human mammary carcinoma cell line (BT 20) into nude mice. J Natl Cancer Inst 1974;52:1669-72.

54. Outzen HC, Custer RP. Growth of human normal and neoplastic mammary tissues in the cleared mammary fat pad of the nude mouse. J Natl Cancer Inst 1975;55:1461-6.

55. Cabioglu N, Summy J, Miller C, Parikh NU, Sahin AA, Tuzlali S, et al. CXCL-12/stromal cell-derived factor-1alpha transactivates HER2-neu in breast cancer cells by a novel pathway involving Src kinase activation. Cancer Res 2005;65:6493-7.

56. Orimo A, Gupta PB, Sgroi DC, Arenzana-Seisdedos F, Delaunay T, Naeem R, et al. Stromal fibroblasts present in invasive human breast carcinomas promote tumor growth and angiogenesis through elevated SDF-1/CXCL12 secretion. Cell 2005;121:335-48.

57. Price JE, Polyzos A, Zhang RD, Daniels LM. Tumorigenicity and metastasis of human breast carcinoma cell lines in nude mice. Cancer Res 1990;50:717-21.

58. Cailleau R, Young R, Olive M, Reeves Jr WJ. (1974). Breast tumor cell lines from pleural effusions. J Natl Cancer Inst 53:661-74

59. Muller A, Homey B, Soto H, Ge N, Catron D, Buchanan ME, et al. Involvement of chemokine receptors in breast cancer metastasis. Nature 2001;410:50-6.

60. Kuperwasser C, Chavarria T, Wu M, Magrane G, Gray JW, Carey $\mathrm{L}$, et al. Reconstruction of functionally normal and malignant human breast tissues in mice. Proc Natl Acad Sci USA 2004;101:4966-71.

61. Kuperwasser C, Dessain S, Bierbaum BE, Garnet D, Sperandio K, Gauvin GP, et al. A mouse model of human breast cancer metastasis to human bone. Cancer Res 2005;65:6130-8.

62. Nusse R, van Ooyen A, Cox D, Fung YK, Varmus H. Mode of proviral activation of a putative mammary oncogene (int-1) on mouse chromosome 15. Nature 1984;307:131-6.

63. van de Vijver M, van de Bersselaar R, Devilee P, Cornelisse C, Peterse J, Nusse R. Amplification of the neu (c-erbB-2) oncogene in human mammary tumors is relatively frequent and is often accompanied by amplification of the linked c-erbA oncogene. Mol Cell Biol 1987;7:2019-23.

64. Stewart TA, Pattengale PK, Leder P. Spontaneous mammary adenocarcinomas in transgenic mice that carry and express MTV/myc fusion genes. Cell 1984;38:627-37.

65. Ichaso N, Dilworth SM. Cell transformation by the middle Tantigen of polyoma virus. Oncogene 2001;20:7908-16.

66. Guy CT, Cardiff RD, Muller WJ. Induction of mammary tumors by expression of polyomavirus middle $\mathrm{T}$ oncogene: a transgenic mouse model for metastatic disease. Mol Cell Biol 1992;12:954-61.

67. Fluck MM, Haslam SZ. Mammary tumors induced by polyomavirus. Breast Cancer Res Treat 1996;39:45-56.
68. Lopez JI, Camenisch TD, Stevens MV, Sands BJ, McDonald J, Schroeder JA. CD44 attenuates metastatic invasion during breast cancer progression. Cancer Res 2005;65:6755-63.

69. Almholt K, Lund LR, Rygaard J, Nielsen BS, Dano K, Romer J, et al. Reduced metastasis of transgenic mammary cancer in urokinase-deficient mice. Int J Cancer 2005;113:525-32.

70. Ma Z, Gibson SL, Byrne MA, Zhang J, White MF, Shaw LM. Suppression of insulin receptor substrate 1 (IRS-1) promotes mammary tumor metastasis. Mol Cell Biol 2006;26:9338-51.

71. Bugge TH, Lund LR, Kombrinck KK, Nielsen BS, Holmback K, Drew AF, et al. Reduced metastasis of Polyoma virus middle $\mathrm{T}$ antigen-induced mammary cancer in plasminogen-deficient mice. Oncogene 1998, 16:3097-104.

72. Schoeffner DJ, Matheny SL, Akahane T, Factor V, Berry A, Merlino G, et al. VEGF contributes to mammary tumor growth in transgenic mice through paracrine and autocrine mechanisms. Lab Invest 2005;85:608-23.

73. Ross JS, Fletcher JA. The HER-2/neu oncogene in breast cancer: prognostic factor, predictive factor, and target for therapy. Stem Cells 1998;16:413-28.

74. Stern, DF. Tyrosine kinase signalling in breast cancer: ErbB family receptor tyrosine kinases. Breast Cancer Res 2000;2: 176-83.

75. Di Fiore PP, Pierce JH, Kraus MH, Segatto O, King CR, Aaronson SA. erbB-2 is a potent oncogene when overexpressed in NIH/3T3 cells. Science 1987;237:178-82.

76. Muller WJ, Sinn E, Pattengale PK, Wallace R, Leder P. Singlestep induction of mammary adenocarcinoma in transgenic mice bearing the activated c-neu oncogene. Cell 1988;54:105-15.

77. Guy CT, Webster MA, Schaller M, Parsons TJ, Cardiff RD, Muller WJ. Expression of the neu protooncogene in the mammary epithelium of transgenic mice induces metastatic disease. Proc Natl Acad Sci USA 1992;89:10578-82.

78. Dankort D, Maslikowski B, Warner N, Kanno N, Kim H, Wang Z, et al. Grb2 and Shc adapter proteins play distinct roles in Neu (ErbB-2)-induced mammary tumorigenesis: implications for human breast cancer. Mol Cell Biol 2001;21:1540-51.

79. Siegel PM, Massague J. Cytostatic and apoptotic actions of TGF-beta in homeostasis and cancer. Nat Rev Cancer 2003; 3:807-21

80. Muraoka RS, Koh Y, Roebuck LR, Sanders ME, BrantleySieders D, Gorska AE, et al. Increased malignancy of Neuinduced mammary tumors overexpressing active transforming growth factor beta1. Mol Cell Biol 2003;23:8691-703.

81. Muraoka-Cook RS, Kurokawa H, Koh Y, Forbes JT, Roebuck LR, Barcellos-Hoff MH, et al. Conditional overexpression of active transforming growth factor betal in vivo accelerates metastases of transgenic mammary tumors. Cancer Res 2004;64: 9002-11.

82. Yang YA, Dukhanina O, Tang B, Mamura M, Letterio JJ, MacGregor J, et al. Lifetime exposure to a soluble TGF-beta antagonist protects mice against metastasis without adverse side effects. J Clin Invest 2002;109: 1607-15.

83. Forrester E, Chytil A, Bierie B, Aakre M, Gorska AE, SharifAfshar AR, et al. Effect of conditional knockout of the type II TGF-beta receptor gene in mammary epithelia on mammary gland development and polyomavirus middle $\mathrm{T}$ antigen induced tumor formation and metastasis. Cancer Res 2005;65:2296-302.

84. Boccaccio C, Comoglio PM. Invasive growth: a MET-driven genetic programme for cancer and stem cells. Nat Rev Cancer 2006;6:637-45

85. Smolen GA, Muir B, Mohapatra G, Barmettler A, Kim WJ, Rivera $\mathrm{MN}$, et al. Frequent met oncogene amplification in a Brca1/Trp53 mouse model of mammary tumorigenesis. Cancer Res 2006;66:3452-5. 
86. Lee WY, Su WC, Lin PW, Guo HR, Chang TW, Chen HH. Expression of S100A4 and Met: potential predictors for metastasis and survival in early-stage breast cancer. Oncology 2004; 66:429-38.

87. Takayama H, LaRochelle WJ, Sharp R, Otsuka T, Kriebel P, Anver M, et al. Diverse tumorigenesis associated with aberrant development in mice overexpressing hepatocyte growth factor/ scatter factor. Proc Natl Acad Sci USA 1997;94:701-6.

88. Jeffers M, Fiscella M, Webb CP, Anver M, Koochekpour S, Vande Woude GF. The mutationally activated Met receptor mediates motility and metastasis. Proc Natl Acad Sci USA 1998;95:14417-22.

89. Gallego MI, Bierie B, Hennighausen L. Targeted expression of HGF/SF in mouse mammary epithelium leads to metastatic adenosquamous carcinomas through the activation of multiple signal transduction pathways. Oncogene 2003;22:8498-508.

90. Maggiora P, Marchio S, Stella MC, Giai M, Belfiore A, De Bortoli $\mathrm{M}$, et al. Overexpression of the RON gene in human breast carcinoma. Oncogene 1998;16:2927-33.

91. Lee WY, Chen HH, Chow NH, Su WC, Lin PW, Guo HR. Prognostic significance of co-expression of RON and MET receptors in node-negative breast cancer patients. Clin Cancer Res 2005;11:2222-8.

92. Zinser GM, Leonis MA, Toney K, Pathrose P, Thobe M, Kader SA, et al. Mammary-specific Ron receptor overexpression induces highly metastatic mammary tumors associated with beta-catenin activation. Cancer Res 2006;66:11967-74.

93. Cardiff RD, Anver MR, Gusterson BA, Hennighausen L, Jensen RA, Merino MJ, et al. The mammary pathology of genetically engineered mice: the consensus report and recommendations from the Annapolis meeting. Oncogene 2000;19:968-88.

94. Jonkers J, Berns A. Conditional mouse models of sporadic cancer. Nat Rev Cancer 2002;2:251-65.

95. Lewandoski M. Conditional control of gene expression in the mouse. Nat Rev Genet 2001;2:743-55.

96. Gunther EJ, Belka GK, Wertheim GB, Wang J, Hartman JL, Boxer RB, et al. A novel doxycycline-inducible system for the transgenic analysis of mammary gland biology. FASEB J 2002 16:283-92.

97. Gossen M, Freundlieb S, Bender G, Muller G, Hillen W, Bujard $H$. Transcriptional activation by tetracyclines in mammalian cells. Science 1995;268:1766-9.

98. Fisher GH, Orsulic S, Holland E, Hively WP, Li Y, Lewis BC, et al. Development of a flexible and specific gene delivery system for production of murine tumor models. Oncogene 1999;18:5253-60.

99. Du Z, Podsypanina K, Huang S, McGrath A, Toneff MJ, Bogoslovskaia $\mathrm{E}$, et al. Introduction of oncogenes into mammary glands in vivo with an avian retroviral vector initiates and promotes carcinogenesis in mouse models. Proc Natl Acad Sci USA 2006;103:17396-401.

100. Borresen-Dale AL. TP53 and breast cancer. Hum Mutat 2003; 21:292-300.

101. Stange DE, Radlwimmer B, Schubert F, Traub F, Pich A, Toedt G, et al. High-resolution genomic profiling reveals association of chromosomal aberrations on $1 \mathrm{q}$ and $16 \mathrm{p}$ with histologic and genetic subgroups of invasive breast cancer. Clin Cancer Res 2006; $12: 345-52$

102. Lin SC, Lee KF, Nikitin AY, Hilsenbeck SG, Cardiff RD, Li A, et al. Somatic mutation of $\mathrm{p} 53$ leads to estrogen receptor alphapositive and -negative mouse mammary tumors with high frequency of metastasis. Cancer Res 2004;64:3525-32.

103. Derksen PW, Liu X, Saridin F, van der Gulden H, Zevenhoven J, Evers B, et al. Somatic inactivation of E-cadherin and p53 in mice leads to metastatic lobular mammary carcinoma through induction of anoikis resistance and angiogenesis. Cancer Cell 2006;10:437-49.

104. Weinstein IB. Cancer. Addiction to oncogenes - the Achilles heal of cancer. Science 2002;297:63-4.

105. Weinstein IB, Joe AK. Mechanisms of disease: Oncogene addiction - a rationale for molecular targeting in cancer therapy. Nat Clin Pract Oncol 2006;3:448-57.

106. Sharpless NE, DePinho RA. Cancer biology: gone but not forgotten. Nature 2007;445:606-7.

107. Moody SE, Sarkisian CJ, Hahn KT, Gunther EJ, Pickup S, Dugan KD, et al. Conditional activation of Neu in the mammary epithelium of transgenic mice results in reversible pulmonary metastasis. Cancer Cell 2002;2:451-61.

108. de Visser KE, Eichten A, Coussens LM. Paradoxical roles of the immune system during cancer development. Nat Rev Cancer 2006;6:24-37.

109. Condeelis J, Pollard JW. Macrophages: obligate partners for tumor cell migration, invasion, and metastasis. Cell 2006;124:263-6.

110. Orimo A, Weinberg RA. Stromal fibroblasts in cancer: a novel tumor-promoting cell type. Cell Cycle 2006;5:1597-601.

111. Edinger M, Cao YA, Hornig YS, Jenkins DE, Verneris MR, Bachmann $\mathrm{MH}$, et al. Advancing animal models of neoplasia through in vivo bioluminescence imaging. Eur $\mathrm{J}$ Cancer 2002;38:2128-36

112. Weissleder R, Ntziachristos V. Shedding light onto live molecular targets. Nat Med 2003;9:123-8.

113. Heyn C, Ronald JA, Ramadan SS, Snir JA, Barry AM, MacKenzie LT, et al. In vivo MRI of cancer cell fate at the single-cell level in a mouse model of breast cancer metastasis to the brain. Magn Reson Med 2006;56:1001-10.

114. Abbey CK, Borowsky AD, Gregg JP, Cardiff RD, Cherry SR Preclinical imaging of mammary intraepithelial neoplasia with positron emission tomography. J Mammary. Gland. Biol Neoplasia 2006;11:137-49.

115. Weissleder R. Scaling down imaging: molecular mapping of cancer in mice. Nat Rev Cancer 2002;2:11-8.

116. Condeelis J, Segall JE. Intravital imaging of cell movement in tumours. Nat Rev Cancer 2003;3:921-30.

117. Sidani M, Wyckoff J, Xue C, Segall JE, Condeelis J. Probing the microenvironment of mammary tumors using multiphoton microscopy. J Mammary Gland Biol Neoplasia 2006;11:151-63.

118. Tsukamoto AS, Grosschedl R, Guzman RC, Parslow T, Varmus HE. Expression of the int-1 gene in transgenic mice is associated with mammary gland hyperplasia and adenocarcinomas in male and female mice. Cell 1988;55:619-25.

119. Schoenenberger CA, Andres AC, Groner B, van der Valk M, LeMeur M, Gerlinger P. Targeted c-myc gene expression in mammary glands of transgenic mice induces mammary tumours with constitutive milk protein gene transcription. EMBO J 1988;7:169-75.

120. Andres AC, Schonenberger CA, Groner B, Hennighausen L, LeMeur M, Gerlinger P. Ha-ras oncogene expression directed by a milk protein gene promoter: tissue specificity, hormonal regulation, and tumor induction in transgenic mice. Proc. Natl Acad Sci USA 1987;84:1299-303.

121. Whitelaw CB, Harris S, McClenaghan M, Simons JP, Clark AJ. Position-independent expression of the ovine beta-lactoglobulin gene in transgenic mice. Biochem J 1992;286( Pt 1):31-9.

122. Allison J, Zhang YL, Parker MG. Tissue-specific and hormonal regulation of the gene for rat prostatic steroid-binding protein in transgenic mice. Mol Cell Biol 1989;9:2254-7.

123. Palmiter RD, Sandgren EP, Koeller DM, Brinster RL. Distal regulatory elements from the mouse metallothionein locus stimulate gene expression in transgenic mice. Mol Cell Biol $1993 ; 13: 5266-75$ 
124. Turksen K, Kupper T, Degenstein L, Williams I, Fuchs E. Interleukin 6: insights to its function in skin by overexpression in transgenic mice. Proc Natl Acad Sci USA 1992;89:5068-72.

125. Pravtcheva DD, Wise TL. Metastasizing mammary carcinomas in H19 enhancers-Igf2 transgenic mice. J Exp Zool 1998;281:43-57.

126. Maroulakou IG, Anver M, Garrett L, Green JE. Prostate and mammary adenocarcinoma in transgenic mice carrying a rat $\mathrm{C} 3$ (1) simian virus 40 large tumor antigen fusion gene. Proc Natl Acad Sci USA 1994;91:11236-40.

127. Liu CH, Chang SH, Narko K, Trifan OC, Wu MT, Smith E, et al. Overexpression of cyclooxygenase-2 is sufficient to induce tumorigenesis in transgenic mice. J Biol Chem 2001;276:18563-9.

128. Kwan H, Pecenka V, Tsukamoto A, Parslow TG, Guzman R, Lin $\mathrm{TP}$, et al. Transgenes expressing the Wnt- 1 and int- 2 protooncogenes cooperate during mammary carcinogenesis in doubly transgenic mice. Mol Cell Biol 1992;12:147-54.

129. Kwak EL, Kim S, Zhang J, Cardiff RD, Schmidt EV, Haber DA. Mammary tumorigenesis following transgenic expression of a dominant negative CHK2 mutant. Cancer Res 2006;66:1923-8.

130. Davies MP, Rudland PS, Robertson L, Parry EW, Jolicoeur P, Barraclough R. Expression of the calcium-binding protein
S100A4 (p9 Ka) in MMTV-neu transgenic mice induces metastasis of mammary tumours. Oncogene 1996;13:1631-7.

131. Siegel PM, Shu W, Cardiff RD, Muller WJ, Massague J. Transforming growth factor beta signaling impairs Neu-induced mammary tumorigenesis while promoting pulmonary metastasis. Proc Natl Acad Sci U S A 2003;100:8430-5.

132. Guo W, Pylayeva Y, Pepe A, Yoshioka T, Muller WJ, Inghirami G et al. Beta 4 integrin amplifies ErbB2 signaling to promote mammary tumorigenesis. Cell 2006;126:489-502.

133. Cuevas BD, Winter-Vann AM, Johnson NL, Johnson GL. MEKK1 controls matrix degradation and tumor cell dissemination during metastasis of polyoma middle-T driven mammary cancer. Oncogene 2006;25:4998-5010.

134. Nielsen LL, Discafani CM, Gurnani M, Tyler, RD. Histopathology of salivary and mammary gland tumors in transgenic mice expressing a human Ha-ras oncogene. Cancer Res 1991;51:3762-7.

135. Schulze-Garg C, Lohler J, Gocht A, Deppert W. A transgenic mouse model for the ductal carcinoma in situ (DCIS) of the mammary gland. Oncogene 2000;19:1028-37.

136. Gallahan D, Jhappan C, Robinson G, Hennighausen L, Sharp R, Kordon E, et al. Expression of a truncated Int 3 gene in developing secretory mammary epithelium specifically retards lobular differentiation resulting in tumorigenesis. Cancer Res 1996;56:1775-85. 